\title{
Critical Pedagogy in Postgraduate Classroom: Students' Perspectives
}

\author{
Hazir Ullah $^{*}$
}

\begin{abstract}
Postgraduate classroom, in pedagogical discourses, is a physical space where learners can interact with their teachers and other learners, where they can share their experiences, ideas and knowledge, and put them into action for their individuals and collective change. This paper examines whether postgraduate classroom in Pakistan provides learners with the opportunity to widen their intellectual horizon through interactive learning and prepare them for jobs in the competitive knowledge based economy or equip them with 'inflated credentials'. The data informing this study were gathered during fall 2015 semester from 20 (10 MS/M. Phil and $10 \mathrm{Ph}$. D) scholars at two public sector universities of Islamabad. Drawing on qualitative data, the paper employed Foucauldian discourses analysis as the key methodological and theoretical tool for understanding how postgraduate students describe their learning experience. Analyzing the data with the insights from Foucauldian discourses analysis (FDA), the paper explores a number of concerns, including the constitutive and constituted nature of teachers' practices and teachers' ideology. The study findings suggest that majority of the universities' teachers are preachers rather than teachers. The paper stresses for the recognition and application of critical pedagogy in our postgraduate classroom. Based on the study findings, the paper suggest that postgraduate scholars should be treated as intellectuals who will engage in dialogue with their teachers and their peers to test their ideas and knowledge against the ideas and opinions of their teachers and class fellows.
\end{abstract}

Keywords: Pedagogical discourses, Foucauldian discourse analysis, inflated credentials, critical pedagogy

Associate Professor, Department of Sociology, International Islamic University, Islamabad 


\section{Introduction}

Universities are institutions that are expected to provide high quality education. As national economies increasingly shift from mass production to a 'knowledge economy', it is inevitable that universities are expected to train highly qualified workforce to meet a range of societal needs (Rassenfosse \& Williams, 2015). Many countries around the world, including Pakistan, have stated goals of increasing both access to and participation in higher education (Organization for Economic Cooperation and Development (OECD), 2012).

Keeping the importance of higher education in contemporary credential societies, successive governments in Pakistan have placed an emphasis on quality education as a major driver of socio-economic development and social mobility. The recognition of territory education as the major driver of economic competitiveness in the increasing knowledge based global economy led to the development of Higher Education Commission (HEC) in 2002 through an Ordinance for the evaluation, improvement and development of higher education through quality teaching and research. For the development of higher education sector, HEC embarked on strategic reforms, i.e. faculty development, spreading the web of university across the countries, ensuring access to higher education for the disadvantage through scholarship, stressing university to start MS/M. Phil and Ph. D programme. At the face value, there is encouraging growth in the number of universities and academic disciplines offering admission in MS and Ph. D programmes. Nevertheless, these developments need to be examined critically.

A series of government initiatives over the last 13 years have been taken to improve the quality of research and infrastructures of higher education institutions. Quality Assurance Agency (QAA) at the HEC and Quality Enhancement Cell (QEC) in the universities has been established. Most of these initiatives are teachers centred that incrementally raised their social status and profile with little attention to students.

Nevertheless, little or no attention has been given to classroom interaction and its improvement, except few training sessions at the HEC head office. Being a teacher of one of the largest and reputed public sector university, I do not see any programme or comprehensive strategy, neither on the part of HEC nor universities, which suggests a movement away from the traditional 'banking model of education' (Freire, 1970; 
1973) to a more interactive learning or student centered classroom environment.

It is pertinent to stress here that classroom is one of the most important interactive spaces in the universities where learners can interact with other learners and with teacher, where they can share their experiences and previous knowledge, and put them into action for their individuals and collective change. Postgraduate classroom provides students with opportunities to test their ideas and opinions against the ideas and opinions of their teachers and peers. Similarly, coursework [which takes place dominantly in face to face classroom teaching] is a 'powerful teaching and learning activity that can help the [MS and] PhD students to attain the intended learning outcomes of the programme (Moreno, 2014). Stressing the importance of classroom teaching, it can be argued that postgraduate classroom should enable teachers and learners to have shared perception of power exercise in the classroom. This means that both teachers and students are aware of power and its outcome.

The concept of power is used in a wide variety of academic disciplines. The meaning and definition of power vary from one discipline to another and even within a given discipline. It will divert the focus of the paper if I review all of the ways the term "power" is used by different scholars in different disciplines. Rather, I am attempting to take into account power that is pertinent in sociology of education. This study, thus, takes into account power, agency and critical pedagogy as key concepts in its theoretical framework.

\section{Theoretical Underpinning}

Power/dominance in classroom discourses is one of the key concepts informing the analysis. Power in classical sociology refers to the ability of an individual to get someone else to do what s/he wants him/her to do. Power means the control over other. Dahl (1957: 202) asserted that "A has power over $\mathrm{B}$ to the extent that he can get $\mathrm{B}$ to do something that $\mathrm{B}$ would not otherwise do". The existing postgraduate classroom reflects this dominant power structure where teachers control students to the extent that they can get students to do what students do not otherwise do.

This study, however, goes further and use Michal Foucault's concept of power. Unlike classical sociologists Weber (1925) \& Dahl (1957), Foucault analyzed modern power as a mobile and constantly shifting set of force relations that emerge from every social interaction and thus pervade the social body. He argues that "power is everywhere, not 
because it embraces everything, but because it comes from everywhere" (Foucault, 1978: 93). Foucault criticizes the classical analyses of power (Marxist and Freudian) for assuming that power is fundamentally repressive, a belief that he terms the "repressive hypothesis" (1978, 1749). Albeit Foucault does not disagree that power sometimes functions repressively (1978), he maintains that it is primarily productive. Foucault (1977: 194) further claims that "power produces; it produces reality; it produces domains of objects and rituals of truth." It also, according to Foucault, produces subjects. According to Foucault, modern power subjects individuals, in both senses of the term; it simultaneously creates them as subjects by subjecting them to power. For Foucault, power influences not only what we can say and do but how we can say and do them. It also influences the opportunities we have to do so. In characterizing the multifaceted nature of power, Foucault does not mean that we are without choice. Each of us makes choices in our daily lives. These choices may be reflected in the way we dress, the food we eat, the gestures we make, and the words we speak or choose not to speak. Choice is the equivalent of what has been termed 'agency'. Drawing on Foucault, it can be argued that the existing pedagogical practices at postgraduate classroom divest students of their agency.

In sociology, agency is the capacity of individuals to act independently and to make their own free choices (Ullah, 2013). An individual's agency is his/her independent ability to act on his/her will. This human ability is affected by the belief structure which he/she has formed through his/her experiences, and the perceptions held by the society and the individual, of the structures and circumstances of the environment one is in and the position s/he is born into (Smith, 2004). Disagreement on the extent of one's agency often causes disagreement and conflict between parties, e.g. teacher and students. Education, especially higher education, is believed to develop an individual agency and to enable him/her to negotiate the process that is going in his/her social world, including classroom. The current practices in Pakistani higher education limit students' agencies and their free decisions. With an insight from Foucault's Discipline and Punish, it can be argued that the current practices of higher education in Pakistan shape the postgraduate scholars as docile bodies. In order to enable learners and make them aware that they also possessed power and can exercise it in making subject choice, teacher choice, testing their ideas against their teacher and peers, we need critical pedagogy in our classrooms that question the existing hegemonic teaching learning process. 
Critical pedagogy in this study is used in the same sense as it was used by Paulo Freire. Freire (1970) argued that students have the ability to think critically about their education situation. He further asserted that thinking critically allows them to "recognize connections between their individual problems and experiences and the social contexts [including education] in which they are embedded" (Freire 1970: 13). Critical pedagogy helps students question and challenge posited "domination," and to undermine the beliefs and practices that are alleged to dominate. According to Critical pedagogues, i.e., Shor \& Freire (1987) and Apple (1995) etc, education (here postgraduate classroom) must enable students to develop reading, writing and thinking capacities that go beneath surface meaning, first impressions, dominant myths, official pronouncements, traditional clichés, received wisdom, and mere opinions, to understand the deep meaning, root causes, social context, ideology, and personal consequences of any action, event, object, process, organization, experience, text, or discourse. Critical pedagogy in classroom discourse embodies the practice of engaging students in the social construction of knowledge, which grounds its pillars on power relations. Utilizing critical pedagogy in the classroom, teachers must question their own practices in the process to construct knowledge and why the main knowledge is legitimized by the dominant culture.

\section{Methodology}

As discussed in the abstract and theoretical framework, this study is based on qualitative data. I chose qualitative approach for a number of reasons, the most important being that I found no studies that interrogated the students' perspectives on their learning experience in postgraduate classroom. How they feel about their higher studies and their effects, in their opinion, on the intellectual horizon and research skills. The use of qualitative research allowed me to understand the meanings that postgraduate students gave to their learning experiences of MS/M. Phil and Ph. D coursework. My interest in this study came from a long observation of students' discussions and complaints about their M. Phil and Ph. D coursework in different spaces: in university canteen, sitting and waiting for their teachers in front of their classrooms and even texts messages that I received from ex-students who are perusing their higher studies at different universities.

The data informing this research were gathered during fall 2015 from 20 (10 MS and $10 \mathrm{Ph}$. D) students in two public sector universities of 
Islamabad. Both institutions claim to be committed to the quality of higher education in their mission statements. The study was restricted to the students of social sciences discipline. Participants were selected from a pool of students who had completed their coursework and were preparing for their theses. They were selected by employing stratified random sampling. The data was collected through open ended questionnaire. I opted for open ended questions in order to get as detailed responses as possible. Through the open coding, students' responses were organized into eight categories. Constant comparison of these categories were carried out to see how some categories should be grouped together to condense them into meaningful themes. This exercise condensed the broad categories into four powerful themes. This was done with the help of close coding. See Flick (2009) for the open and close coding details. My own experience as M. Phil and Ph. D students as well as teacher of postgraduate programme facilitated and shaped the interpretation of the participants' responses that may have been missed by a more removed observer. It is important to mentioned here that these responses and statements from the small sample may not be attributed as few voices of the selected postgraduate learners, but may be taken into account as representation of the widespread belief that postgraduate students hold about the higher education. Despite the fact that the paper uses data from a small sample (only two public sector universities of Islamabad), the findings do highlight the dismaying status of teaching and learning practices at the postgraduate level which may be utilize to study the issue at the national level in the best interest of the future of higher education in Pakistan.

\section{Findings}

To briefly summarize the main findings from my research, participants gave the following meaning to their experiences in their higher education.

- Higher Education: an opportunity to enhance knowledge and boost career prospects:

- The current pedagogical practices at the postgraduate block critical learning capacity

- Student led-teaching

- The oppressors and oppressed actors in our higher education

- $\quad$ Old wine in new vessels 


\section{Higher Education: An Opportunity to Enhance Knowledge and Boost Career Prospects}

A consistent theme that emerged from students responses were that; ... they got admission in MS/M. Phil and Ph. D to increase their knowledge and get a more rewarding career. When asked about whether their M. Phil and Ph. D coursework improved their knowledge and intellectual horizon?, a significant that majority (14 out of 20) of the participants were disappointed with their coursework. Below are some of quotations from the responses of Ph. D students in which they expressed their concern. One of the female Ph. D scholar stated, “I didn't learn much when I compare it with my previous knowledge that I got in MSc and MS/M. Phil”. In almost similar tone another female argued, "with the exception of two subjects, I have learned noting new and interesting". Another student shared her experience of learning as, "I experienced the same methodology, same style of examination, same way of delivering lecture and most importantly the same ways of producing puppets not real scholars can create new knowledge”. Another female Ph. D student asserted,

There was nothing new. I would say it was worst than what I learned during my MS coursework. In MS teachers used to come to class with preparations while in the $\mathrm{Ph}$. D classes, they came without preparations and divide the course outlines among us and ask to present it to the class.

Another MS/M. Phil student, explaining her experience of MS coursework, stated,

"I did not get the knowledge what I expected at the time of admission. The teachers did not have enough knowledge about the course they taught. Some teachers did not even bother to teach us by saying you are MS scholar and at this stage teachers do not give lectures".

Research unpacks that teacher preparation for the classroom are among the key factors in teacher effectiveness. Well prepared teachers develop learners' interest in learning and gaining knowledge. It is also asserted that students of the well prepared teachers outperform those who do not prepare for the class. Expressing his concern, another MS student opined that "what we will learn when some of the teachers who thought us were unable to communicate their message. They were unable to speak fluently and we were unable to get anything from his teaching”

These responses are indicatives of the fact most students (with the exception of the few) are disappointed with their MS and Ph. D coursework and feel their coursework hasn't met the expectations that they had at the time of admission. This situation may not be dismissed 
with a statement that the 'issue of keeping students happy and satisfied is not pertinent for universities'.

\section{The Current Model of Higher Education Blocks Capacity}

Over a short period of time, higher education processes, both research and teaching, have brought students to accept and tolerate increasing injustice and subjection. When asked about the classroom as an interactive space where teacher and students can enter into dialogue, where they can attest and challenge each other opinion, following experience were shared.

A female Ph. D scholar stated, "Asking a question is a sin. They [Teachers] say good children do not ask questions. Whatever is told by the teachers [professors] is correct, so be quiet in the class if you want to pass the course".

The above statement replaces the old western issue "teacher questioning and pupil anxiety” (Dillon, 1990; Wood, 1991) with a new Pakistani issue "pupils questioning and teacher anxiety". Another male $\mathrm{Ph}$. D scholar argued, "Broadly speaking, classroom did not give me an opportunity to opine. Whenever, I dared to ask question the answer was extremely unsatisfactory".

The MS/ M. Phil scholars explained their experiences of the classroom in almost similar ways. A female M. Phil student said, "I asked questions in the class and got satisfactory answers from my teachers. However, when I disagreed with the teachers' argument, the teachers always tried to convince me to accept their point of view".

There is nothing wrong with getting along with teachers or disagreeing with him/her as disagreement and discussion is the foundation of knowledge. However, our postgraduate classroom operates as a hierarchical space where teachers determine what is knowledge and how that knowledge can be expressed. The point to be stressed here is that the university professors are expected to be teachers rather preachers. Another student argued,

"I asked questions and spoke up in classroom. But on confusing or critical questions teachers told to find the answer and present explanation in the next class to the whole class. I tried not to ask questions if I have to find out the answer."

In the above quote there is a tacit element of discouraging a student not to ask question. And if s/he asks, s/he has to find an answer to his/her question not only for him/her but for the entire class. This kills the essence of classroom which expects teachers and students to enter into a 
dialogue and to be jointly responsible for the process in which all grow (Freire, 1994). Another male MS student argued, "MS classroom provided us a space to ask questions but it was useless to ask a question as whenever I asked questions, I rarely got satisfactory answer. I decided to be silent in the class."

At the face value, these quotations seem to be encouraging. Nevertheless, a critical look unveils the fact that in reality teachers invalidate students' knowledge and limit their agency. Taken together, the quotations above construct the actors (teachers and students) in the postgraduate classroom as oppressors and oppressed and show power as something wielded by a few over the many ( Foucault, 1977 ).

\section{Students’ Led-teaching}

The century old banking model of education (teaching and learning process in which teachers are active subjects and students are passive objects) is no more effective and relevant. Freire (1994) sharply criticized the "banking concept" (1994:53) of education, in which an allknowing teacher deposits knowledge into passive students. In the banking model, pupils are restricted to receiving, filing, and storing the information deposited by the teachers, and in the end it is "the people themselves who are filed away through the lack of creativity" (1994:53). Freire stressed to introduce a laboratory pedagogy that is based on "dialogue and problem-solving in which, teachers and students are both Subjects, not only in the task of unveiling that reality, and therefore by coming to know it critically, but in the task of re-creating that knowledge." (1994:51). He emphasized on the importance of "dialogue between teachers and learners who are jointly responsible for the teaching process in which all grow (1994:61). It is argued that in a laboratory pedagogy practices teachers role is of facilitator, who jump in as they feel appropriate to add additional perspectives, help answer questions, or raise new ways of looking at concepts and issues. In such teaching and learning processes, a number of teachers and students formed very tight bonds, with some of the more advanced students corresponding regularly in private with teachers to further discuss issues.

Drawing on insights from Freire's approach to pedagogy, it can be argued that the situation in our postgraduate classroom is different and dismaying. Following quotations from the study's data unveils what is going on in our postgraduate classrooms. A Ph. D scholar argued, "We taught to each other. Most of the teachers were silent spectators. They even did not listen to our presentation.” Another female Ph. D scholar revealed, 
"Most of our teachers divided the course outlines among us with a plan of presentation. In every class two to three students were supposed to give lecture and generate discussions. Most of the teachers even did not know and were not bothered what the students are presenting. Sometimes students presented and shared totally wrong information and the teacher did not correct them. Most of the students remained quiet in the class. Some students tried to engage in dialogue with the presenter which always led to further confusion as the teacher was unable to clarify.

The following quotation explicates the postgraduate classroom as, We [the students] presented the major parts of the courses during class-time. Teachers occasionally taught us. Mostly teachers were mentally absent or were busy with their mobiles during our presentations. They did not even know what we were talking about. One day, a student was giving presentation and suddenly teacher started laughing. We wondered what happened. The teacher told that she remembered a funny incident and then she shared with us. This shows teachers attitude towards classes.

The above statements, detailing the teaching and learning process in postgraduate classroom, highlight teachers' disinterest in what is going on in his/her classes. Almost everyone agrees that student presentations benefit the presenter in significant ways. Through class presentations, students learn how to speak in front of a group. It enables them to get professional skills. They learn how to prepare material for public presentation with feedback from their peers. However, the class responds to these presentations when the teacher actively participates and talks. Students attend more carefully to what their classmates are saying when the evaluations they are doing "count" and are either agreed or disagreed by the teachers and the presenter. The responses in this study show that students were equally clear that they did not want the evaluations of their peers to have any role in improving the presenter or determining their grade for the presentation. It is highly desired that the teacher considers the learning potential of presentations, not just for the presenter, but for the rest of students (Baranowski \& Wei, 2011).

\section{The Oppressors and Oppressed in our Higher Education}

Classroom is a social relationship where politics exists, albeit less discussed academically. Classroom politics is felt by every student and teacher at one time or another. The sociology of education refers to it as a kind of "hidden curriculum". What is "hidden" is a social performance underneath the academic performance that could influence one's grade. One of the female Ph. D scholars argued, 
"Higher education is too much political. The professors start politic in the classroom. Students, whether interested or not, get involved. Some become spy on other students and even on other teachers and in and out of class activities for the professor. While some become victim of politics and those who keep up with the professor are bestowed with good grades and many more favors.

This quotation is one of the several quotes that are indicative of the fact that a constant 'surveillance and observation' (Foucault 1979) has been established to control those who intend to question the unjust system or teaching and learning process. Another male Ph. D scholar stated, "Doing a $\mathrm{PhD}$ was really a dream for me yet I had a worse experience of academic politics while during my coursework." Similarly, another $\mathrm{Ph}$. D scholar argued,

"Teachers satisfy their insecurities at the cost of students. Teachers sustain the status quo. They used students for the self interest even if it destroys students' careers. We need to eliminate politics from our higher education/ educational institutions in order to improve the quality of higher education.”

The existing higher education in the study locale, Freire would argue, is an instrument of oppression-teachers as oppressors and students as oppressed (Preire, 1994). This, in Foucauldian sense, is subjection of students to the power structure where the subjects (students) have little, if any, self-determinate agency (Foucault, 1979). This kind of academic culture seems to kill the essence of education-education as liberating practice. The oppressive relationship in higher education institutions contradicts the Higher Education Commission's goal of “creating a critical mass of highly qualified [citizens] that could contribute towards the development of Pakistan" (HEC website). We need liberatory pedagogy / critical pedagogy enabling students to free themselves from unequal power relations (Preire, 1994).

\section{Change without Change}

The study findings suggest that most of the subjects and classroom teaching at higher education reflects what the postgraduate students learned in their undergraduate programme. A lot number of respondents asserted that they [teachers] are here to sustain the same old patterns and system which does not serve the requirement of today higher education. The existing coursework and style stop any productive change (extract from interviews). Similarly, another Ph. D scholar said, "I did not experience any change. Same methodology, same theories, same 
concepts, same style of examination, same way of delivering lecture and most importantly the same culture of producing the puppets [and docile bodies] not real scholars."

The overall claim the can be establish here is that the existing postgraduate coursework and pedagogical practices in Pakistan reflect a phenomenon similar to the idiom: "old wine in new vessels."

\section{Conclusion}

It is important to realize that the perspectives of students in this study may not represent the views and perspectives of the students across Pakistan and across disciplines. Nevertheless, what can be summarized from these findings is that these findings may stress and help university teachers and policy makers to think about issues which have arisen and may arise in our higher education in the coming decades. The study findings suggest that the current practices in our higher education qualify the majority of faculty members as 'preacher' rather than 'teacher'. By preacher I mean a person who pass on the messages and believe that what s/he says is correct and the audience have to agree with him/her; whereas teachers, in Freire sense, is the one who listen to audience (students) think of them creator of knowledge. The current system of postgraduate teaching does not make teachers accountable and has vested in them an absolute power. Based on the study findings, my assertion is that the situation is alarming. To be truly responsive to the calls for improving higher education, universities may have to rethink the core mission of postgraduate teaching and research and revisit their evaluation system and its values to ensure postgraduate classroom to be a place that engages learners in larger ideological discourses, promoting their agency and knowledge so that they influence their immediate personal lives and communities. What keeps me up at night is what kind of jobs and what kind of ultimate opportunities are available to our students if we do not equip them with high quality knowledge and skills or they do not acquire substance knowledge to trade upon. It also bothers to think what is the future of Pakistani higher education? 


\section{References}

Apple, M.W. (1995). Education and Power. New York: Rout ledge.

Baranowski, M., and Weir, K. (2011). Peer evaluation in the political science classroom. PS, Political Science and Politics, 44 (4), 805811.

Dahl, R. (1957). The Concept of Power. Behavioral Science, 2, 201-15.

Dillon, J.T. (1990). The Practice of Questioning. London and New York: Rout ledge.

Flick, U. (2009). An Introduction to Qualitative Research (4 ${ }^{\text {th }}$ ed). Los Angeles and London: Sage Publication.

Freire, P. (1970). Pedagogy of the Oppressed. New York: The Continuum Publishing Company.

Freire, Paulo. (1973). Education for Critical Consciousness. New York: Seabury.

Freire, P. (1994). Pedagogy of the Oppressed ( $3^{\text {rd }}$ ed.). New York: Continuum Publishing Company.

Foucault, M. (1977). Discipline and Punish: The Birth of the Prison. New York: Pantheon.

Foucault, M. (1978). The history of sexuality: An introduction. Hammonsworth: Penguin.

Foucault, M. (1979). Discipline and punish: The birth of the prison. New York: Vintage Books.

Moreno, R. (2014). Management of the Level of Coursework in PhD Education: A Case of Sweden, Journal of Applied Economics and Business Research 4 (3): 168-177 
Organization for Economic Cooperation and Development (OECD). (2012). Education indicators in focus series, in Working Papers Series, No. 15, OECD Publishing

Rassenfosse, G. \& Williams, R. (2015). Rules of engagement: measuring connectivity in national systems of higher education. Higher Education, 70(6) 941-956.

Shor, I. \& Freire, P. (1987). A pedagogy for liberation. Westport, CT: Greenwood.

Smith, D. (2004). Schooling for inequality. In J. Spade \& C. Valentine (eds), The Kaleidoscope of gender: Prisms, Patterns, and possibilities (pp.183-186).Belmont, Ca, Wadsworth.

Ullah, H. (2013). The Reproduction of Class and Gender Hierarchies through Different Education System in Khyber Pakhtunkhwa, Ph. D Dissertation, University of Peshawar, Pakistan

Weber, M. (1925). Status Groups and Classes, in Guenther, R. \& Claus, W. (eds), in economy and society (pp. 926-939). Berkeley: University of California Press

Wood, D. (1991). Aspects of teaching and learning" in Light, P., Sheldon, S., \& Woodhead, M (1991) Learning to Think, Routledge: London.

Received on: January 28, 2016

Revised on: May 24, 2016

Accepted on: June 02, 2016 